\title{
Blue Growth: Sea Urchin Sustainable Aquaculture, Innovative Approaches
}

\author{
Tamara Rubilar ${ }^{1,2 *} \&$ Dana Cardozo ${ }^{3}$
}

1. Laboratory of Chemistry of Marine Organisms, Instituto Patagónico del Mar, National University of Patagonia San Juan Bosco, Bv. Alte. Brown, Puerto Madryn, Argentina; rubilar@cenpat-conicet.gob.ar (*Correspondence).

2. Biological Oceanography Laboratory CESIMAR, CCT CENPAT,CONICET, Bv. Alte. Brown, Puerto Madryn, Argentina.

3. University of Quilmes, Departamento de Postgrado, Roque Sáenz Peña Bernal, Buenos Aires Argentina; dcardozo3@uvq.edu.ar

\author{
Received 24-VII-2020. Corrected 10-XI-2020. Accepted 11-XI-2020.
}

\begin{abstract}
Introduction: "Blue Economy" refers to ocean-based economies with a sustainable approach. It focuses in smaller carbon footprints and efficiency, principles that can be applied to aquaculture. However, it has been difficult to develop successful blue economy projects in sea urchin aquaculture. Objective: To compare URCHINOMICS (Norway) and ARBACIA (Argentina), two aquaculture projects with different business models. Methods: We used publicly available information to compare both companies on the basis of their value proposition and tensions (e.g. cultural, social economic and technological). Results: To be successful, sea urchin aquaculture requires development of appropriate technology, open innovation and cooperation of people with different academic, business and organizational backgrounds. Conclusion: The ultimate success of these and similar companies will depend on free interaction of experts from multiple fields and on technological innovation.
\end{abstract}

Key words: sea urchin; circle economy; aquaculture; Arbacia; urchinomics; business model; sustainable.

Blue revolution is often referring to the rapid development of aquaculture and to the creation of an agricultural activity with a high productivity (McGinn, 1998; Costa-Pierce, 2002; Movik, Mehta, Mtisi, \& Nicol, 2005; Simpson, 2011). This blue revolution is responsible for the increment in food production worldwide (Béné et al., 2016; FAO, 2020). However, aquaculture has important different environmental issues that must be address (Hall et al., 2011; Ahmed \& Thompson, 2019). Sea urchin aquaculture, as any aquaculture activity must learn from the experience, failures and successes of the blue revolution, and improve its practices and developing long-term solutions to mitigate the environmental concerns as water waste, use of antibiotics, organic matter waste, etc. (Ahmed \& Thompson, 2019) and generate commercial products.

Blue Economy refers to ocean-based economies with a sustainable approach (UNDESA, 2014). The focus is to have a compatibility between economic development and ocean health (WWF, 2015). In this way, it considers the carbon footprint (it should be low), the efficiency in the use of resources (specially water), 
and presents the possibility of create different economic ventures around it (aquaculture, fisheries, tourism, maritime transport, marine biotechnology, renewable energy) (World Bank \& UNDESA, 2017). The FAO (2018) launched the Blue Growth initiative for oceans, seas and coasts. This initiative aims to develop aquaculture and fisheries taking in account the ecosystems, the environmental and the economic impact. In this way, any aquaculture enterprise under the Blue Economy framework, should have incorporate the sustainable development and incorporate social, economic and environmental benefits (UNDESA, 2014).

Since sea urchins have been consumed since the beginning of humanity (Lawrence, 2007), the industry that exploit them should engage in a Blue Economy framework. The historical basis of this industry is the fishing and consumption of the gonads, known in the market as "uni" (oonee), "caviar de oricios", "roe" or "sea urchin caviar". There has been a major decline in the number of sea urchin species supplying the international market in the last few years, from landings of around 120000 ton in 1995 to the current levels of about 75000 ton (Stefánsonn, Kristinsonn, Ziemer, Hannon, \& James, 2017). Only a few species show the highest level of fishing pressure, with 32 thousand ton for Loxechinus albus and 25 thousand ton for Strongylocentrotus spp. (FAO, 2020). The sea urchin roe market is very traditional in Japan, a country that accounts over $80 \%$ of the global consumption the seafood (Brown \& Eddy, 2015) Consumer demand for sea urchins is driven by several key market factors, including innovation and experimentation, convenience, and health (Stefánsonn et al., 2017). Sea urchin roe is a delicacy served in sushi bars, restaurants and at wedding banquets (Sun \& Chiang, 2015). For centuries the roe has been consumed in Mediterranean countries in sauces, with pasta, breads, as well as in custards and ice-cream (Wise, 2008; Gangi 2011; Stefánsonn et al., 2017). There have been a variety of efforts to generate new species entrants into the market, such as the Project DIADEMAR a private-public consortium that developed a novel sea urchin pate from Diadema africanum in the Canary Islands (González-Henríquez, 2012). Other species have been studied on the Pacific coast of America, such as Loxechinus albus in the coast of Peru-Chile (Yamashiro-Guinoza, Benites-Rodrigez, Zeballos-Flor, Tafur-Jimenez, 1996; Lawrence, Olave, Otaiza \& Lawrence, 1997; Olave, Bustos, Lawrence \& Carcamo, 2001; Ayerbe-Ochoa et al., 2018), Tripneustes depressus in México and Ecuador (Vives-Pérez, 2018; Sonnenholzner-Varas, Touron \& Panchana-Orrala, 2018; Sonnenholzner-Varas, Moreira \& Panchana-Orrala, 2019), and Arbacia stellata in Ecuador (Jorge Sonnenholzner, Comm. Pers., 2020).

Roe is often thought to be the main product from sea urchins. However, in the 1980s, the USSR pharmaceutical industry initiated the first studies on naphthoquinone pigments, commonly known as Spinochromes, from sea urchins in the Far East of Russia. Russian scientists found that Echinochrome A, a molecule belonging to the spinochrome family, extracted from the testes and spines has cardioprotective action and healing properties for ocular diseases and they developed two drugs, "Histochrome" and "Gistochrome" which were commercially approved in Russia (FSP R002363/02-260213 Manufacturer's Pharmacopeia Article; Mischenko, Fedoreyev \& Bagirova, 2003; US6410601B2; Mischenko et al., 2005; Lebed'ko, Ryzhavskii, \& Demidova, 2015; Vasileva, Mischenko, \& Fedoreyev, 2017; Fedoreyev et al., 2018a; Fedoreyev et al., 2018b; Shikov, Pozharitskaya, Krishtopina, \& Makarov, 2018; Yoon et al., 2019; Oh et al., 2019; Barbieri et al., 2020; Rubilar et al., 2020). There are also biologically active foods being developed with naphthoquinone pigments from sea urchins, such as Thymarin, Sea Hematogen and AXIVOS $®$ (Table 1). In this manner, the actives principle present in sea urchin testes and spines have been used commercially in an innovatively. However, this is still based on harvesting sea urchin. Still, on the positive side, it would appear that it has been evidenced that there are real benefits for human health (Shikov et al., 2018; Itoh et al., 2016; 
TABLE 1

Biological active foods from sea urchin extracts develop for marketing

\begin{tabular}{llll}
\multicolumn{1}{c}{ Product } & \multicolumn{1}{c}{ Country } & \multicolumn{1}{c}{ Description } & \multicolumn{1}{c}{ Use } \\
Axivos & New Zeland \& Russia & $\begin{array}{l}\text { Extract of sea urchin on fructosa and } \\
\text { Vitamin C (BBA) }\end{array}$ & $\begin{array}{l}\text { Sea urchin pigments for diabetes type } \\
1 \text { and } 2\end{array}$ \\
Sea Hematogen & Russia & $\begin{array}{l}\text { Syrup with antioxidant properties with } \\
\text { raw honey and sea urchin extract }\end{array}$ & $\begin{array}{l}\text { Preserves the maximum amount of } \\
\text { substances useful for human health }\end{array}$ \\
Thymarin & Russia & $\begin{array}{l}\text { Honey or fructose formulation with } \\
\text { Vitamin C and Echinochrome A }\end{array}$ & Dietary supplment \\
& & &
\end{tabular}

Vasileva et al., 2017; Yoon et al., 2019; Artyukov et al., 2020), and marketable products have been developed to meet the increasing demand for these pigments.

Sea urchin aquaculture has its own very unique background and history (Fig. 1) but all of the possible uses of sea urchins clearly indicate that there is a requirement to meet the demands of a number of areas, including quality roe production, naphthoquinone pigments and drug discovery. In spite of the obvious potential and research advances made to date, according to Sun and Chiang (2015), it has been difficult to find successful examples of sea urchin aquaculture. Still, even though it has been stated that sea urchin aquaculture is a risky business (Smith, 2017), many countries and companies have been making efforts to overcome the risks stumbling blocks. Examples can be found in China, Japan, Norway, Canada,
Ireland, Italy, Scotland, New Zealand, among others. The interesting attempts cannot always be seen to be reflected in the number of publications regarding aquaculture development in the last 10 years; nor are these efforts reflected in the number of patents generated around the world concerning sea urchin aquaculture.

In this work we attempt to do a basic review regarding the sea urchin aquaculture attempts and the difficulties these enterprises have as well as to examine to new examples with Blue Economy in their core and present an innovative approach in their projects.

\section{Experiences regarding sea urchin species consumed and culture}

We will present the aquaculture attempts in the main fished species around the world. These are not the only examples of sea urchin aquaculture; however, they showed the big

\section{Background}

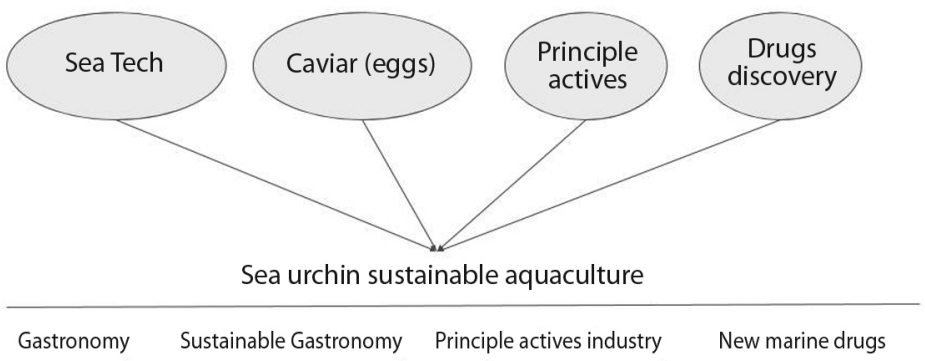

Fig. 1. Background and history of the sea urchin aquaculture according to requirement to meet different demands. 
picture in sea urchin aquaculture development. China initiated sea urchin aquaculture studies in the 1980 s and by the 2000s started to produce considerable numbers of sea urchins, motivated by the market demand for urchin roe (Sui, 1981; Zhou, 1982; Liao 1985; Sun, Hu, Li, \& Liu, 1989; Gao, Hu, \& Sun, 1990). China adapted the processes used for other species, such as finfish, shellfish, and seaweeds as sea urchins have not been the main focus of Chinese aquaculture. No specially designed sea urchin hatcheries exist and, therefore, larvae are usually cultivated in ordinary shellfish or abalone hatcheries. China has achieved the production of 10 million seeding and around 6000 ton annually, however this data is from 10 years ago (Liu \& Chang, 2015). Strongylocentrotus nudus is the most widely cultured species with $S$. intermedius (Liu \& Chang, 2015). There has been an increase in landbased tank development for sea urchin broodstock conditioning in narrow rectangular tanks with a flow-through commonly used in other aquaculture species. This generates expensive juveniles due to the cost of heating the water. To alleviate this cost, there have been efforts to modulate spawning periods to obtain early seedlings (Liu \& Chang, 2015). There is only one brand formulated feed for sea urchins commercialized by Dalian Pacific Seafood Co. Ltd, who also process iced roe, frozen and canned products from sea urchin aquaculture and these are sold to Japan (https://www.zhangzidao. $\mathrm{cn}$ /products?lang=en). Other feeds have been developed by small aquaculture companies but they have not been commercialized.

In Japan, the sea urchins that are consumed are wild; there are at least six major edible sea urchin species: $S$. intermedius, $S$. nudus, Hemicentrotus pulcherrimus, Pseudocentrotus depressus, H. crassispina, and Tripneustes gratilla. Due to the incredible pressure on sea urchin fisheries in Japan, there is a government effort to reseed the natural stocks. In this context, this reseeding is not considered to comprise an aquaculture activity. The majority of the production is focused on S. intermedius and most of the hatcheries are located in the same region, Hokkaido. To produce the seedlings, broodstock is held in large tanks with flow through seawater with 100 sea urchins. In Japan, there are two types of sea urchin aquaculture, one with the whole life cycle based on aquaculture and the other incorporating a shortterm aquaculture improving the gonad quality of the wild animals. These activities started in the 1980s but is still not widely implemented in Japan (Unuma, Sakai, Agatsuma, \& Kayaba, 2015). There were attempts during the 1980s to apply this to $P$. depressus and $S$. intermedius (Uchiba \& Yamamoto, 1983; Uchiba, 1984; Uchiba,1985). Currently, there are sea-based and land-based aquaculture systems. In the seabased systems, the technology used is similar to the one used for shellfish. This requires a small capital investment but demands strong and competent management and small boats as the feeding, sorting and harvesting take place in the sea and is, therefore, weather dependent. On the other hand, the land-based operations are at early stage and are not yet profitable. These facilities have been converted from existing ones used, originally, for other species (Unuma et al., 2015).

Although Chile accounts for approximately fifty percent of global roe production, entirely by harvesting L.albus, and has the largest sea urchin fishery in the world (Moreno et al., 2007; Sun \& Chiang, 2015), aquaculture is not yet developed. Heavy fishing pressure has resulted in a reduction in production by fifty percent along the Chilean Coast, making it unsustainable (Stotz, 2004). The Chilean government and fisherman are implementing restocking and reseeding programs (Cárcamo, 2004), especially in small scale harvesting locations. There have been public and private efforts to only produce restock sea urchins (Espinoza-Alvarado \& ArriagadaMoreira, 2017).

Strongylocentrotus droebachiensis is widely distributed in the Arctic-Boreal (Sivertsen, 1997; Scheibling \& Hatcher, 2001; Blicher, Rysgaard, \& Sejr, 2007) and is a species that has been the subject of research and aquaculture efforts undertaken by a number of 
countries. In the 1990's in the US and Canada, began researching about hatcheries, restocking, and gonad enhancement methods (Walker \& Lesser, 1998; Robinson, Castell, \& Kennedy, 2002; Pearce, Daggett, \& Robinson, 2002, 2003, 2004; Pearce, Williams, Yuan, Castell, \& Robinson, 2005). At that time, there were three different hatcheries established in the northeast of the US for seeding production. Columbia Island Scallops Ltd. in British Columbia was able to produce up to 750000 seedings in 2000; however, the company is no longer focused on sea urchins (McBride, 2005). Peacock Cannery was another producer of seedings which is no longer producing. Green Seafoods tried in 2000 to establish sea urchin aquaculture in Canada, but the correct feeding of the animals and getting roe to a marketable size were important issues that could not be overcome and they abandoned the project (Sherrat, 2018). Green Seafoods has once again taken up the challenge and has been working together with the Norwegian based company, URCHINOMICS on feed innovation. For more than 30 years, research has been going on in a variety of countries, including countries that have no established sea urchin fisheries, such as Norway. In addition to research, there have been numerous smallscale ventures to establish profitable sea urchin aquaculture. ScanAqua AS was a sea-based roe-enhancement farm in Hammerfest but is no longer in operation (James, Siikavuopio, \& Mortensen, 2015). There are two other companies in Norway focusing on sea urchin aquaculture (Troms Kråkebolle AS, Sea Urchin Farm AS) since the mid-2000s. In Norway, Nofima (The Norwegian Institute of Food, Fisheries and Aquaculture Research) has focused on the development of feed for the broodstock diet and on enhancement of sea urchin roe quality to avoid the use of macroalgae (Siikavuopio, Christiansen, Sæther, \& Dale, 2006; Siikavuopio, Dale \& Mortensen, 2007; Siikavuopio, Mortensen, \& Christiansen, 2008). In Russia, there is an interest on behalf of scientists and businessmen to develop sea urchin aquaculture in the Barents Sea; however, to date, there has been a lack of funding (Dvoretsky \& Dvoretsky, 2020).

\section{Innovative approaches}

While one can find various, on-going efforts to produce or increase the production of roe for human consumption to meet the global food demand, there are fewer examples of companies addressing both environmental challenges and food production on a large scale, using innovative techniques. However, there are two examples, located on opposite sides of the globe and with completely different innovative approaches, who are trying to tackle some of the shortcomings of the industry and who propose new aquaculture methods and techniques to meet the Blue Economy framework.

URCHINOMICS, a company based in Norway with a global reach and organization, is just such a "pioneer" in this field. Focused on an environmental challenge, namely the restoration of ocean habitats to lead to sustainable food production, URCHINOMICS proposes to harvest sea urchins to eliminate the extreme overgrazing of kelps along coastal areas and, then, to produce, in a land-based facility, premium sea urchin roe. The company presents itself as a restorative aquaculture venture aiming to turn an environmental challenge into a commercial, ecological and social opportunity. It is privately funded by a European investment group (www.urchinomics.com). URCHINOMICS benefits from more than 30 years of research on $S$. droebachiensis. They propose to solve environmental problems on which they are focusing while making aquaculture and respond to the demand for roe. URCHINOMICS works globally with fishermen, scientists, ecologists and distribution partners and have been particularly active in sea urchin feed development with a strong cooperation in this field with Nofima. URCHINOMICS are confident of their success as they believe that sea urchins are easy to farm and that in ten weeks they can improve the roe (Sherrat, 2018). With operations in Japan, Canada and the US, URCHINOMICS has now opened its 
first land-based sea urchin ranch in Norway in Stavanger Municipality, which is still in a pilot stage. Together with Nofima, URCHINOMICS is part of the large Horizon 2020 project AquaVitae which focuses on sustainable, low-trophic aquaculture and which includes looking at sea urchin aquaculture and logistics (Waycott, 2020).

Geographically far from URCHINOMICS's new land-based operation in Norway, one finds a completely new aquaculture approach involving an unexpected species, in an unexpected country, Argentina. Here, one finds ARBACIA, a spin-off from the national research council, CONICET, with strong ties to local universities (Universidad Nacional de la Patagonia San Juan Bosco and Universidad Tecnologica Nacional) and is privately funded from shrimp fishery industry. ARBACIA presents itself as an aquaculture venture aiming at developing organic aquaculture for healthier fish and consumers (www.arbacia.com.ar). ARBACIA has been founded and conceived to work as a driver behind the global movement to improve the aquaculture industry and food production practices. The company benefits from 15 years of research in the sea urchin species Arbacia dufresnii, as well as from 20 years of research on the naphthoquinone undertaken by Russian scientists. ARBACIA aims to produce principle actives and biologically active additives (BBA) based on sea urchin eggs to improve human health and result in a sustainable commercial, environmental and social impact. One area of focus is on the chronicdisease prevention in humans by using marine natural products. And with the upcoming pandemia, ARBACIA has focus their efforts in a treatment for COVID-19. ARBACIA is a land-based operation with a comprehensively designed program for waste control, as well as for the tracing and control of the environmental footprint. The company's working methods and techniques are based on an ethical approach towards sea urchins (Rubilar \& Crespi, 2017; Crespi \& Rubilar, 2018; Crespi \& Rubilar, in press) where the sea urchins are cultivated from the egg to the adult, where no cruelty is involved and where the eggs are harvested without harming the animals. Arbacia's core focus is on increasing the amount of active principles (spinochromes, astaxanthin, amino acids, fatty acids, cholines, phospholipids, vitamins and minerals) in the eggs and on harvesting every 8 weeks. Business-wise, this is important as wild sea urchins spawn only once a year (Epherra et al., 2014) but by increasing the amount of active principles and the frequency of egg harvesting, there is the possibility of securing a stronger potential commercial basis for this type of operation. ARBACIA has developed its technology based on biotechnology, sea-tech, other aquaculture ventures and, most important, all of this has been specifically modelled for a particular species Arbacia dufresnii. The tanks, the RAS, the feed and the control of the production variables are all based on the requirements of this species. A.dufresnii is not commonly thought of as an edible sea urchin. In fact, it is often rejected by the roe market due to its color and texture. However, these same features make it perfect for the production of eggs with a high concentration of healthy principle actives

Both projects have something in common: their innovative culture. This culture refers to the natural way to applied problem solving based on innovation. An innovative culture is one that leads the organization towards a way of functioning that incorporates a systematic, continuous learning mode, that is, with a permanent training perspective in order to know how to adapt to new contexts, new technologies and business models (Marcet, 2014).

We have analyzed both of these innovative companies on the basis of their value proposition (Ballantyne, Frow, Varey \& Payne, 2011; Pokorná, Pilar, Balcarová \& Sergeeva, 2015; Sire et al. 2019). To do so we analyzed the tensions (cultural, social economic, technological, etc.) inherent in the sea urchin aquaculture industry to secure a harmonic status between science and business (Joffre, Klerkx, Dickson \& Verdegem, 2017; Andriopoulos \& Lewis, 2009). We chose to represent this as a spring in order to visualize the assumption that when 
the tension is released and a common language and objective is secured, the project may be successful as in the SECI model the spring progressively forms more complex knowledge with each cycle (Nonaka \& Takeuchi, 1995; Nonaka, Toyama \& Konno, 2000; Bandera, Keshtkar, Bartolacci, Neerudu \& Passerini, 2017; Nonaka \& Takeuchi, 2019).

URCHINOMICS centers its innovation around the environmental challenge of restoring the kelp forests while feeding the world (Fig. 2). This project is able to clearly understand a serious environmental challenge and propose a novel an innovative solution based on a high demand product, the sea urchin roe. URCHINOMICS has applied previous experience of sea urchin aquaculture and seatech already in place. The feed that Nofima developed was the key to kick off URCHINOMICS's project. URCHINOMICS is aimed not only at tackling an environmental issue, but also at producing sea urchin feed with a diminished carbon footprint, thereby working towards the United Nations Sustainable Development Goals 2 Zero Hunger. In this way URCHINOMICS proposes an environmentally sustainable business model with cutting edge technology and an innovative approach.
ARBACIA centers it innovation around the sea urchin Arbacia dufresnii and the health of consumers (Fig. 3). The company aims at improving the way aquaculture products are produced by focusing on the most important factor, that is, resistance to antimicrobials (FAO, 2018), with the goal of producing healthier fish and consumers. ARBACIA produced innovative extracts from sea urchin eggs with active principles reducing the use of antibiotics in fish aquaculture. The company also focuses on human health, producing biologically active additives (BBA) for human consumption. They have applied previous knowledge developed by Russian scientists and commercial ventures already in place based on other sea urchin extracts. In the Russian case this is from the testes and spines (https:// tifarm.su/). ARBACIA has invested significant funds and energy in developing sea-tech specifically for $A$. dufresnii aquaculture, as well as in developing a feed which diminishes the carbon footprint. The critical point in the transition from a project to a company is the scalability of production and the business and financial assessments. Marketing and design thinking are key factors in the development of commercial products from science-based

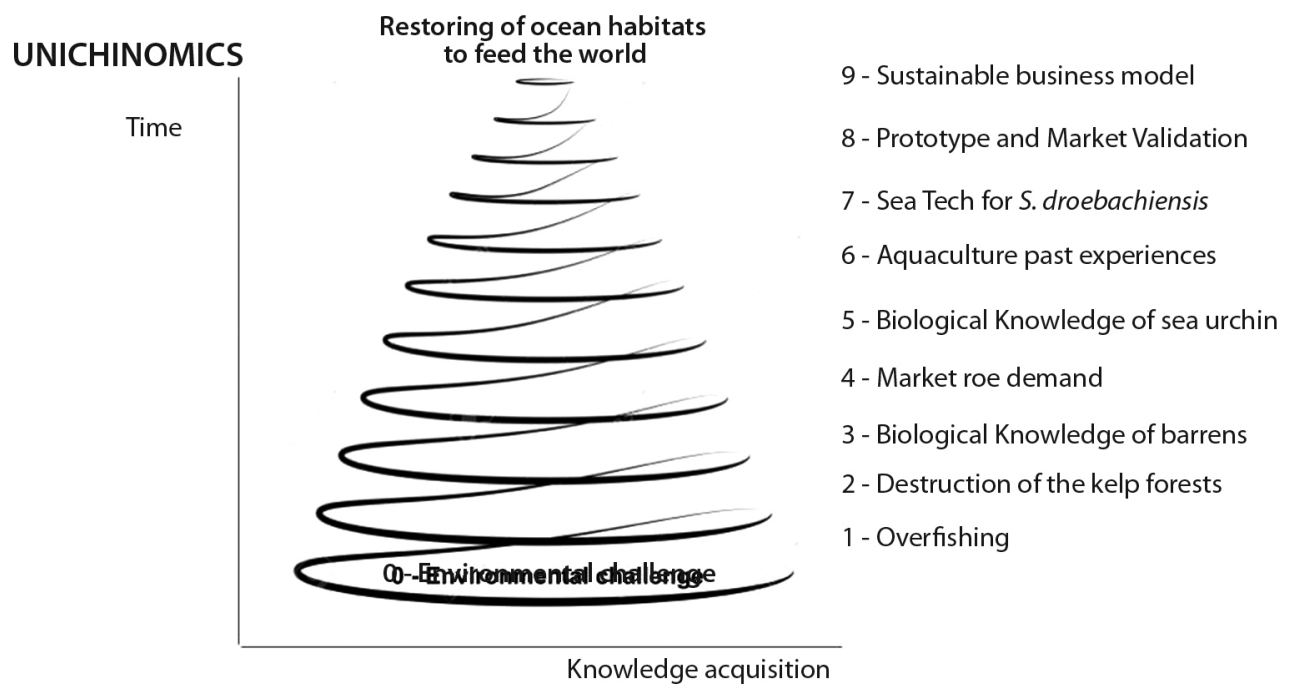

Fig. 2. Schematic spring that visualize Urchinomics project. 


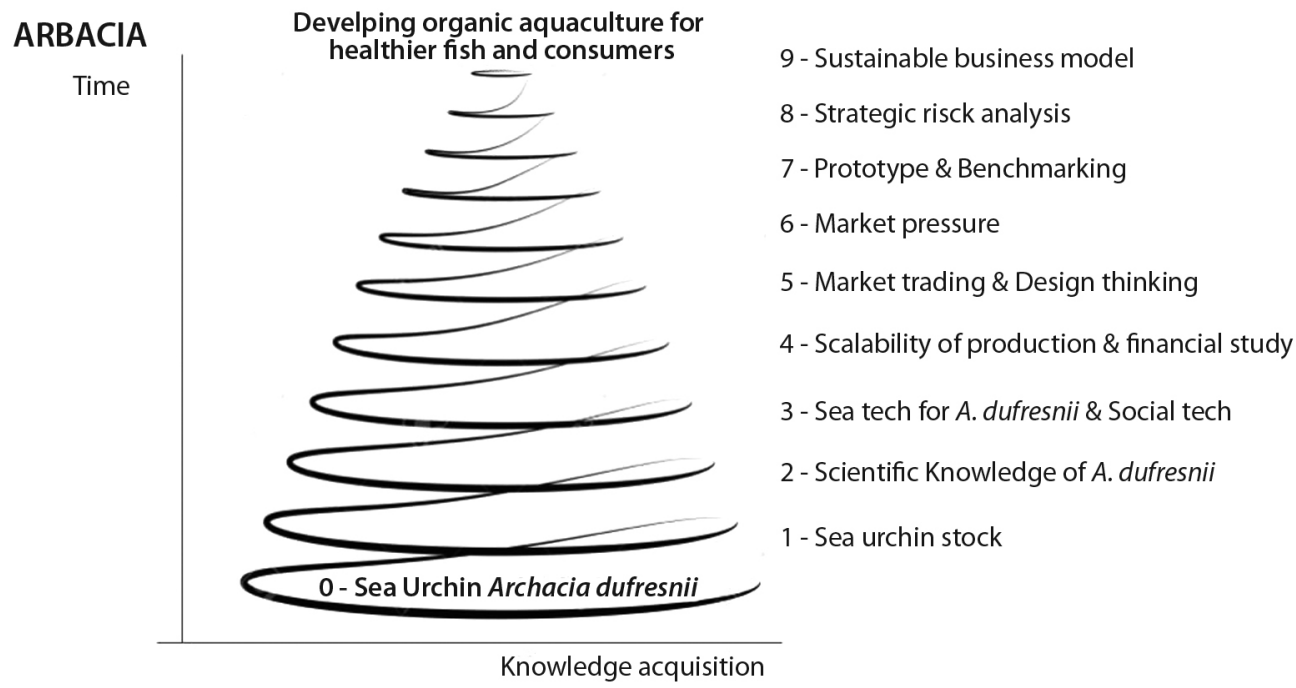

Fig. 3. Schematic spring that visualize Arbacia project.

projects into commercial products. ARBACIA understands that the food industry is going through a huge transformation and that healthier products, supplements and BBA are in demand worldwide (Stirling \& Kruh; 2015; Pinder, Walsh, Orndorff, Milton, \& Trescott, 2017). As a result, new products focusing on human health are being developed. This trend has also energized the need of understanding consumers and their demands in terms of the way the manufacture of the animal -based products takes place. In this way, consumers rely, once again, on science and the incorporation of an ethical approach (Rubilar \& Crespi, 2017). They are leading a movement call "Alimentos que curan" in Ibero America, that focus on improve human health through healthy food to widen the social impact of ARBACIA. In the global context, it is necessary to continue to analyze risks in order to bring flexibility to the business model. For example, in a pandemic scenario, this innovative and flexible approach allowed ARBACIA to explore the possibility of using its products for SARS-CoV-2 and there have been satisfactory results to date (Barbieri et al., 2020; Rubilar et al., 2020). ARBACIA has developed the sea-tech and business model by using agro ecological principles in its land-based operations (FAO, 2018). Consequently, ARBACIA proposes an environmentally sustainable business model with cutting edge technology and approach.

The circular economy aims to achieve sustainability and carbon neutrality. To accomplish this, it is important to design models for the optimal use of waste and pollution prevention, ensuring that products, equipment and materials are in use as long as possible, and that natural systems are regenerated (Schmidt et al., 2020). Any aquaculture project or company can aim at reaching carbon neutrality, starting from a high carbon footprint due to the use of feed and mechanical aeration (Boyd, 2013). Consequently, ARBACIA and URCHINOMICS are on track by eliminating fish oil and meal from their feed. URCHINOMICS is also helping to restore natural marine habitats. ARBACIA is helping to ensure the environmental equilibrium by producing land-based sea urchins instead of fishing them as $A$. dufresnii is not a species that produces barrens in the rocky reefs of Patagonia.

Future Perspective: Without a doubt, sea urchin aquaculture is on the global agenda. This can be due to a number of reasons, such 
as the pressure to secure good quality roe or to address the environmental challenge of sea urchin barrens, or in response to the global change in the food industry or to drug discovery pressure. Whatever the reason, there is no doubt that this is an industry that must innovate and advance. In this context, developing seatech specifically for sea urchins has proven to be crucial. The use of fish or shellfish facilities for sea urchin aquaculture has not been effective. Neither has the use of feed developed for other species. The key to success has been open innovation and the cooperative work of people with different backgrounds (scientists, fisherman, ecologists, aquaculture producers, medical, biohackers, feed producers, businessmen and women, investors, governments, etc.), all with the same aim. Both of the companies described here have this in common and can be beneficial to one another and collaborate with each other and with the many other programs and activities underway, such as those undertaken by Pure Ocean, UNESCO, FAO, WHO, Harvard University, AquaVitae, HatchBlue, the Far Eastern Branch of the Russian Academy of Sciences, just to name a few, in order to build up a sustainable sea urchin aquaculture industry worldwide to meet multiple purposes.

Commercially innovative products from sea urchins, i.e. drugs and BBA developed by the Russian scientists, comprised major components in the development of sea urchin aquaculture in Argentina with a focus on human health. This is just one example showing that drug discovery in marine organisms is starting to be a global issue (Abdel-Razek, El-Naggar, Allam, Morsy, \& Othman, 2020; Shin, 2020).

An approach that incorporates biological, technological, social and environmental issues can determine the basis of an open business model. Such an approach incorporates and addresses cultural diversity, power struggles, diverse interests, a broad range of players (scientist, academics, investors, producers, government, non-governmental organizations, etc.) but also considers market aspects (regulations, market demand, price, production costs, etc.), all in all, making possible a sustainable local economic development based on a global perspective.

A successful project could be defined as one that can rapidly respond to global, changing dynamics, reflecting these changes its business model to meet consumers' and society's demands, needs and choices. If this can be accomplished, any number of sea urchin aquaculture projects could be able to be sustainable both economically and environmentally. Time will tell, but we all can hope that sea urchin aquaculture will be a global reality in the near future.

Ethical statement: authors declare that they all agree with this publication and made significant contributions; that there is no conflict of interest of any kind; and that we followed all pertinent ethical and legal procedures and requirements. All financial sources are fully and clearly stated in the acknowledgements section. A signed document has been filed in the journal archives.

\section{ACKNOWLEDGMENTS}

We would like to thanks to Kathleen Anderson for the revision of the English, criticism of the manuscript and her business advice and Clara Volonteri for the final editing. We would like to thank a lot of people and organizations that had been helping us in this venture, we hope we name all of them. First, to the private investors for believing in us. To the public sector for their support, the Chubut government (Science Secretary, Health Minister, Production Minister, COVID-19 Emergency Committee), the Municipality from Puerto Madryn, the National Ministers (Agroindustry, Science and Production) and Institutes, CONICET, INTI, INTA, INPI and Universities (Universidad Nacional de la Patagonia San Juan Bosco, Universidad Tecnológica Nacional and Universidad del Chubut). To the US Embassy and the GIST Program, Venturewell, Fundacion Emprear, Aceleradora El Litoral, Aceleradora CITES, Aceleradora Gridx, Torcuato Di Tella University, IEA Business 
School (Centro de Emprendedores), NAVES, Pan American Energy, Aluar, Mayma (specially Margarita Carlés, Juan Sicardi, Norberto Fraile and Marcelo Baudes), Mercado Libre Sustentable (specially to Guadalupe Marin), ITBA, Hacela Rodar, Social Lab, ID-Core Biotechnology, CIMA, Oxymoron Argentina, Institut Pasteur, Farestaie, Radcliffe Institute from Harvard University, Red Iberoamericana de Equinodermos, Procens, Argentina Challenge, Red Biolangostino Argentina, Lagom, Inntegra Consultora.

\section{RESUMEN}

Introducción: "Economía azul" se refiere a las economías basadas en el océano con un enfoque sostenible. Se enfoca en menores huellas de carbono y eficiencia, principios que se pueden aplicar a la acuicultura. Sin embargo, ha sido difícil desarrollar proyectos exitosos de economía azul en la acuicultura de erizos de mar. Objetivo: Comparar URCHINOMICS (Noruega) y ARBACIA (Argentina), dos proyectos de acuicultura con diferentes modelos de negocio. Métodos: Utilizamos información disponible públicamente para comparar ambas empresas sobre la base de su propuesta de valor y tensiones (por ejemplo, culturales, socioeconómicas y tecnológicas). Resultados: Para tener éxito, la acuicultura de erizos de mar requiere el desarrollo de tecnología adecuada, innovación abierta y cooperación de personas con diferentes antecedentes académicos, empresariales y organizativos. Conclusión: El éxito final de estas y otras empresas similares dependerá de la libre interacción de expertos de múltiples campos y de la innovación tecnológica.

Palabras clave: erizo de mar; economía circular; acuicultura; Arbacia; urchinomics; modelo de negocio; sostenible.

\section{REFERENCES}

Abdel-Razek, A. S., El-Naggar, M. E., Allam, A., Morsy, O. M., \& Othman, S. I. (2020). Microbial Natural Products in Drug Discovery. Processes, 8(4), 1-470.

Ahmed, N., \& Thompson, S. (2019). The blue dimensions of aquaculture: a global synthesis. The Science of the Total Environment, 652, 851-861.

Andriopoulos, C., \& Lewis, M. W. (2009). Exploitationexploration tensions and organizational ambidexterity: Managing paradoxes of innovation. Organization science, 20(4), 696-717.

Artyukov, A. A., Zelepuga, E. A., Bogdanovich, L. N., Lupach, N. M., Novikov, V. L., Rutckova, T. A., \&
Kozlovskaya, E. P. (2020). Marine polyhydroxynaphthoquinone, Echinochrome A: prevention of atherosclerotic inflammation and probable molecular targets. Journal of Clinical Medicine, 11, 1303-1306.

Ayerbe Ochoa, R., Zevallos Feria, S., Castañeda Muñoz, V., Lope, F., Bendita, H., Vizcarra, Y., \& Sanz Ludeña, Y. (2018). Manual: Cultivo de erizo comercial Loxechinus albus en la Región Moquegua. Informe Instituto del Mar Perú 45(2), 210-241.

Ballantyne, D., Frow, P., Varey, R. J., \& Payne, A. (2011). Value propositions as communication practice: taking a wider view. Industrial Marketing Management, 40(2), 202-210.

Bandera, C., Keshtkar, F., Bartolacci, M. R., Neerudu, S., \& Passerini, K. (2017). Knowledge management and the entrepreneur: Insights from Ikujiro Nonaka's Dynamic Knowledge Creation model (SECI). International Journal of Innovation Studies, 1(3), 163-174.

Barbieri, E. S., Rubilar, T., Gázquez, A., Avaro, M., Seiler, E. N., Vera-Piombo, M., et al. (2020). Sea urchin pigments as potential therapeutic agents against the spike protein of SARS-CoV-2 based on in Silico analysis. ChemRxiv, Preprint. https://doi.org/10.26434/chemrxiv.12568595.v1.

Béné, C., Arthur, R., Norbury, H., Allison, E. H., Beveridge, M., Bush, S., Campling, L., Leschen, W., et al. (2016). Contribution of fisheries and aquaculture to food security and poverty reduction: assessing the current evidence. World Development, 79, 177-196.

Blicher, M. E., Rysgaard, S., \& Sejr, K. K. (2007). Growth and production of sea urchin, Strongylocentrotus droebachiensis, in a high-Arctic fjord, and growth along a climatic gradient $\left(64-77^{\circ} \mathrm{N}\right)$. Marine Ecology Progress Series, 341, 89-102.

Boyd, W. (2013). Public utility and the low-carbon future. UCLA Law Review, 61(6), 1614-1710.

Brown, N. P., \& Eddy, S. D. (Eds.). (2015). Echinoderm aquaculture. Hoboken, New Jersey (USA): Wiley Blackwell.

Cárcamo, P. F. (2004). Massive production of larvae and seeds of the sea urchin Loxechinus albus. In J.M. Lawrence \& O. Guzmán (Eds.), Sea Urchins: Fisheries and Ecology (pp. 299-306). Lancaster, Pennsylvania (USA): DEStech Publications Inc.

Costa-Pierce, B. A. (Ed.). (2002). Ecological Aquaculture: The Evolution of the Blue Revolution. Hoboken, Ney Jersey (USA): Wiley-Blackwell.

Crespi-Abril, A. C., \& Rubilar, T. (2018). Ética e invertebrados: análisis de los casos de los cefalópodos y equinodermos. Revista Latinoamericana de Estudios Críticos Animales, 8, 210-232. 
Crespi-Abril, A. C., \& Rubilar, T. Moving forward in the ethical consideration of invertebrates in experimentation: Beyond the Three R's Principle. Revista de Biología Tropical. in press

Dvoretsky, A., \& Dvoretsky, V. (2020). Aquaculture of green sea urchin in the Barents Sea: a brief review of Russian studies. Reviews in Aquaculture, 12(4), 2080-2090

Epherra, L., Gil, D., Rubilar, T., Perez-Gallo, S., Reartes, M. B., \& Tolosano, J. (2014). Temporal and spatial differences in the reproductive biology of the sea urchin Arbacia dufresnii. Marine and Freshwater Research, 66(4), 329-342.

Espinoza-Alvarado, R., \& Arraigada-Moreira, S. (2017). Repoblamiento de Loxechinus albus. Manual de producción de semillas con fines de repoblamiento. Chile: FONDEP, Universidad de Los Lagos, Chile.

FAO. (2018). The State of World Fisheries and Aquaculture (SOFIA). Rome: FAO.

FAO. (2020). The State of World Fisheries and Aquaculture (SOFIA). Rome: FAO.

Fedoreyev, S. A., Krylova, N. V., Mishchenko, N. P., Vasileva, E. A., Pislyagin, E. A., Iunikhina, O. V., \& Leonova, G. N. (2018a). Antiviral and antioxidant properties of Echinochrome A. Marine Drugs, 16(12), 509 .

Fedoreyev, S. A., Krylova, N. V., Mishchenko, N. P., Vasileva, E. A., Lavrov, V. F., \& Leonova, G. N. (2018b). Antiviral activity of histochrome preparation. Vestnik FEB RAS, 6, 145-151.

Gangi, R. (2011). Sea Urchins. Best of Sicily Magazine. http://www.bestofsicily.com/mag/art397.htm.

Gao, X. S., Hu, Q. M., \& Sun, M. Y. (1990). Experiment on larvae culture of Strongylocentrotus nudus (A. Agassiz). Fisheries Sciences, 9, 17-21.

González-Henríquez, N. (2012). Diademar, memoria final. España: Ministerio de Medio Ambiente y Medio Rural y Marino, Gobierno de España.

Hall, S. J., Delaporte, A., Phillips, M. J., Beveridge, M., \& O'Keefe, M. (2011). Blue Frontiers: Managing the Environmental Costs of Aquaculture. Penang, Malaysia: The WorldFish Center.

Itoh, T., Fujiwarab, A., Ninomiyac, M., Maedad, T., Ando, M., Tsukamasab, Y., \& Koketsuc, M. (2016). Inhibitory effects of Echinochrome A, isolated from shells of the sea urchin Anthocidaris cassispina, on antigen-stimulated degranulation in rat basophilic leukemia RBL-2H3 cells chrough suppression of Lyn activation. Natural Product Communications, 11(9), 1303-1306.
James, P., Siikavouopio, S. I., \& Mortensen, A. (2015). Sea Urchin Aquaculture in Norway. In S. D. Eddy \& N. P. Brown (Eds.), Echinoderm Aquaculture (pp. 147176). Hoboken, New Jersey (USA): Wiley Blackwell.

Joffre, O. M., Klerkx, L., Dickson, M., \& Verdegem, M. (2017). How is innovation in aquaculture conceptualized and managed? A systematic literature review and reflection framework to inform analysis and action. Aquaculture, 470, 129-148.

Lawrence, J. M. (2007). The edible sea urchin. In J.M. Lawrence (Ed.), Edible Sea Urchins: Biology and Ecology (pp. 1-6). Amsterdam, UK: Elsevier Science.

Lawrence, J. M., Olave, S., Otaiza, R., Lawrence, A. L., \& Bustos, E. (1997). Enhancement of gonad production in the sea urchin Loxechinus albus in Chile fed extruded feeds. Journal of the World Aquaculture Society, 28(1), 91-96.

Lebed'ko, O. A., Ryzhavskii, B. Y., \& Demidova, O. V. (2015). Effect of antioxidant Echinochrome A on bleomycin-induced pulmonary fibrosis. Bulletin of Experimental Biology and Medicine, 159(3), 351-354.

Liao, C. Y. (1985). The first report on artificial reproduction of sea urchin Hemicentrotus pulcherrimus (Agassiz). Journal of Shandong Ocean College, 15, 74-76.

Liu, H., \& Chang, Y. (2015). Sea urchin aquaculture in China. In S. D. Eddy \& N. P. Brown (Eds.), Echinoderm Aquaculture (pp. 127-146). Hoboken, New Jersey (USA): Wiley Blackwell.

Marcet, X. (2014). Las 4 palancas para construir una cultura innovadora. Retrieved from http://www. xaviermarcet.com/2014/10/las-4-palancas-para-construir-una.html

McBride, S. C. (2005). Sea urchin aquaculture. American Fisheries Society Symposium, 46, 179-208.

McGinn, A. P. (1998). Blue revolution: the promises and pitfalls of fish farming. World Watch 11(2), 10-19.

Mischenko, N. P., Fedoreyev, S. A., Pokhilo, N. D., Anufriev, V. P, Denisenko, V. A., \& Glazunov, V. (2005). Journal of Natural Products, 68, 1390-1393.

Mischenko, N. P., Fedoreyev, S. A., \& Bagirova, V. L. (2003). Histochrome: a new original domestic drug. Pharmaceutical Chemestry Journal, 37, 48-52.

Moreno, C. A., Barahona, N., Molinet, C., Orensanz, J. M., Parma, A. M., \& Zuleta, A. (2007). From crisis to institutional sustainability in the chilean sea urchin fishery. In T. McClanahan \& J. C. Castilla (Eds.), Fisheries Management (pp. 43-67). Hampshire, UK: Blackwell Press. 
Movik, S., Mehta, L., Mtisi, S., \& Nicol, A. (2005). A "Blue Revolution" for african agriculture? IDS Bulletin, 36(2), 41-45.

Nonaka, I., \& Takeuchi, H. (1995). The knowledgecreating company: How japanese companies create the dynamics of innovation. Oxford, UK: Oxford university press.

Nonaka, I., \& Takeuchi, H. (2019). The Wise Company: How companies create continuous innovation. Oxford, UK: Oxford University Press.

Nonaka, I., Toyama, R., \& Konno, N. (2000). SECI, Ba and leadership: a unified model of dynamic knowledge creation. Long range planning, 33(1), 5-34.

Oh, S. J., Seo, Y., Ahn, J. S., Shin, Y. Y., Yang, J. W., Kim, H. K., \& Han, J. (2019). Echinochrome A reduces colitis in mice and induces in vitro generation of regulatory immune cells. Marine Drugs. 17(11). DOI: 10.3390/md17110622.

Olave, S., Bustos, E., Lawrence, J. M., \& Carcamo, P. (2001). The effect of size and diet on gonad production by the Chilean sea urchin Loxechinus albus. Journal of the World Aquaculture Society, 32(2), 210-214.

Pearce, C. M., Daggett, T. L., \& Robinson, S. M. C. (2002). Optimizing prepared feed ration for gonad production of the green sea urchin Strongylocentrotus droebachiensis. Journal of the World Aquaculture Society, 33, 268-277.

Pearce, C. M., Daggett, T. L., \& Robinson, S. M. C. (2003). Effects of starch type, macroalgal meal source, and beta-carotene on gonad yield and quality of the green sea urchin, Strongylocentrotus droebachiensis (Müller), fed prepared diets. Journal of Shellfish Research, 22, 505-519.

Pearce, C. M., Daggett, T. L., \& Robinson, S. M. C. (2004). Effect of urchin size and diet on gonad yield and quality in the green sea urchin (Strongylocentrotus droebachiensis). Aquaculture, 233, 337-367.

Pearce, C. M., Williams, S., Yuan, F., Castell, J. D., \& Robinson, S. M. C. (2005). Effect of temperature on somatic growth and survivorship of early post-settled green sea urchin, Strongylocentrotus droebachiensis (Müller). Aquaculture Research, 36, 600-609.

Pinder, S., Walsh, P., Orndorff, M., Milton, E., \& Trescott, J. (2017). The future of food: New realities for the industry. Dublin, Ireland: Accenture.

Pokorná, J., Pilař, L., Balcarová, T., \& Sergeeva, I. (2015). Value proposition canvas: identification of pains, gains and customer jobs at farmers' markets. AGRIS on-line Papers in Economics and Informatics, 7(4), 123-130.

Robinson, S. M. C., Castell, J. D., \& Kennedy, E. J. (2002) Developing suitable colour in the gonads of cultured green sea urchins (Strongylocentrotus droebachiensis). Aquaculture, 206, 289-303.

Rubilar, T., \& Crespi-Abril, A. (2017). Does Echinoderm research deserve an ethical consideration? Revista de Biología Tropical, 65, 11-22.

Rubilar, T., Barbieri, E. S., Gázquez, A., Avaro, M., VeraPiombo, M., Gittardi, A., et al. (2020). In silico analysis of sea urchin pigments as potential therapeutic agents against SARS-CoV-2: main protease (Mpro) as a target. ChemRxiv, Preprint. https://doi. org/10.26434/chemrxiv.12598487.v1.

Scheibling, R. E., \& Hatcher, B. G. (2001). The ecology of Strongylocentrotus droebachiensis. In J. M. Lawrence (Ed.), Edible SeaUrchins: Biology and Ecology (pp. 271-306). Amsterdam, UK: Elsevier Science.

Schmidt, C., Begin, G. V., Van Houten, F., Close, C., McGinty, D. B., Arora, R., et al. (2020). The circular gap report. Circle Economy. Retrieved from https:// www.circle-economy.com/

Sherrat, R. (2018). Can you farm sea urchins? International Aquafeed https://aquafeed.co.uk/ can-you-farm-sea-urchins-19454

Shikov, A. N., Pozharitskaya, O. N., Krishtopina, A. S., \& Makarov, V. G. (2018). Naphthoquinone pigments from sea urchin: chemistry and pharmacology. Phytochemistry Reviews, 17(3), 509-34.

Shin, J. H. (2020). Natural Products from Marine Fungi. Marine Drugs, 18(5), 230.

Siikavuopio, S. I., Christiansen, J. S., Sæther, B.-S., \& Dale, T. (2006). Seasonal variation in feed intake under constant temperature and natural photoperiod in the green sea urchin (Strongylocentrotus droebachiensis). Aquaculture, 272, 328-334.

Siikavuopio, S. I., Dale, T., Mortensen, A., \& Foss, A. (2007) Effects of hypoxia on feed intake and gonad growth in the green sea urchin, Strongylocentrotus droebachiensis. Aquaculture, 266, 112-116.

Siikavuopio, S. I., Mortensen, A., \& Christiansen, J. S. (2008). Effects of body weight and temperature on feed intake, gonad growth and oxygen consumption in green sea urchin, Strongylocentrotus droebachiensis. Aquaculture, 281, 77-82.

Simpson, S. (2011). The blue food revolution: making aquaculture a sustainable food source. Scientific American, 304(2), 54-61.

Sire P., Prevost E., Guillou Y., Riwan A., \& Saulais P. (2019). How Can TRIZ tools tremendously stimulate the lean canvas analysis to foster start-up business model and value proposition?. In: R. Benmoussa, R. De Guio, S. Dubois \& S. Koziołek (Eds) New Opportunities for Innovation Breakthroughs for Developing Countries and Emerging Economies. TFC 2019. IFIP Advances in Information and Communication 
Technology (pp. 93-105). Cham, Switzerland: Springer International Publishing AG.

Sivertsen, K. (1997). Dynamics of sea urchins and kelp during overgrazing of kelp forests along the Norwegian cost. (Doctoral dissertation). Norwegian College of Fishery Science, University of Tromsø, Norway.

Smith, C. (2017). Sea urchin aquaculture not a sure thing: UMaine expert. New Brunswick https://www.cbc.ca/ news/canada/new-brunswick/sea-urchin-aquaculturenot-a-sure-thing-umaine-expert-1.4236021

Sonnenholzner-Varas, J. I., Touron, N., \& Orrala, M. M. P. (2018). Breeding, larval development, and growth of juveniles of the edible sea urchin Tripneustes depressus: A new target species for aquaculture in Ecuador. Aquaculture, 496, 134-145.

Sonnenholzner-Varas, J. L., Moreira, J. A., \& Orrala, M. M. P. (2019). Growth performance and survival of Holothuria theeli (holothurian) fed with feces of Tripneustes depressus (echinoid): A multi-trophic aquaculture approach. Aquaculture, 512, 734-345.

Stefánsson, G., Kristinsson, H., Ziemer, N., Hannon, C., \& James, P. (2017). Markets for sea urchins: a review of global supply and markets. Skýrsla Matis, 1-45.

Stirling, C., \& Kruh, W. (2015). Nutraceuticals: The future of intelligent food. KPMG International Cooperative. Retrieved from http://www.kpmg.org

Stotz, W. B. (2004) Sea-urchin fisheries: a chilean perspective. In J. M. Lawrence \& O. Guzmán (Eds.), Sea Urchins: Fisheries and Ecology (pp. 3-17). Lancaster, Pennsylvania (USA): DEStech Publications Inc.

Sui, X.L. (1981). The first report on artificial reproduction of sea urchin Strongylocentrotus nudus (A. Agassiz). Fisheries Science and Technology Information, 2, 4-8.

Sun, J., \& Chiang, F. (2015). Use and Exploitation of Sea Urchins. In S. D. Eddy \& N. P. Brown (Eds.), Echinoderm Aquaculture (pp. 25-46). Hoboken, New Jersey (USA): Wiley Blackwell.

Sun, M. Y., Hu, Q. M., Li, G. Y., \& Liu, Y. (1989). Experiment on larvae diet for Strongylocentrotus nudus (A. Agassiz). Fisheries Sciences, 8, 23-26.

Uchiba, S. (1984). Akauni youshoku shiken I. Fukuoka Suisanshikenjou Gyoumu Houkoku, 57, 175-180.

Uchiba, S. (1985). Akauni youshoku shiken II. Fukuoka Suisanshikenjou Gyoumu Houkoku, 58, 105-112.

Uchiba, S., \& Yamamoto, C. (1983). Miriyou tennen akauni, murasakiuni no shouhinka shiken I. Fukuoka Suisanshikenjou Gyoumu Houkoku, 56, 79-88.

UNDESA. (2014). Blue Economy Concept Paper. United Nations Department of Economic and Social Affairs, New York
Unuma, T., Sakai, Y., Agatsuma, Y., \& Kayaba, T. (2015). Sea urchin aquaculture in Japan. In S. D. Eddy \& N. P. Brown (Eds.), Echinoderm Aquaculture (pp. 77-126). Hoboken, New Jersey (USA): Wiley Blackwell.

US6410601B2. Histochrome and its therapeutic use in acute myocardial infarction and ischemic heart disease

Vasileva, E. A., Mishchenko, N. P., \& Fedoreyev, S. A. (2017). Diversity of polyhydroxynaphthoquinone pigments in North Pacific sea urchins. Chemistry \& Biodiversity, 14(9), 170-182.

Vives-Perez, A. (2018). Calidad de la gónada del erizo de mar Tripneustes depresuss (Agassiz, 1863, Echinodermata:Echinoidea) en la Bahía de La Paz, $B C S$, México (Master dissertation). Instituto Politécnico Nacional, México.

Walker, C. W., \& Lesser, M. P. (1998). Manipulation of food and photoperiod promotes out-of-season gametogenesis in the green sea urchin, Strongylocentrutus droebachiensis: implications for aquaculture. Marine Biology, 132, 663-676.

Waycott, B. (2020). The echinoderm cowboys who can help Norway's kelp. The Fish Site. https://thefishsite.com/articles/the-echinoderm-cowboys-who-canhelp-norways-kelp.

Wise, N. (2008). The kiss of the sea urchin. San Diego Reader. http://www.sandiegoreader.com/news/2008/ apr/02/kiss-sea-urchin/\#

World Bank and UNDESA. (2017). The potential of the Blue Economy: increasing long-term benefits of the sustainable use of marine resources for small island developing states and coastal least developed countries. Washington DC, USA: United Nations Department of Economic and Social Affairs, and World Bank.

WWF. (2015). Principles for a Sustainable Blue Economy. Gland, Switzerland: World Wide Fund for Nature.

Yamashiro Guinoza, C., Benites-Rodrigez, C., Zeballos-Flor, J., \& Tafur-Jimenez, R. (1996). Algunos aspectos biológico-pesqueros del recurso erizo Loxechinus albus (Molina, 1782). Instituto del Mar del Perú (IMARPE), Informe Progresivo $\mathrm{N}^{\circ}$ 38 , p. 31 - 44. http://biblioimarpe.imarpe.gob.pe/ handle/123456789/1192

Yoon, C. S., Kim, H. K., Mishchenko, N. P., Vasileva, E. A., Fedoreyev, S. A., Shestak, O. P., Han, J. (2019). The protective effects of Echinochrome A structural analogs against oxidative stress and doxorubicin in AC16 cardiomyocytes. Molecular Cell Toxicology, 15, 407-414.

Zhou, M. L. (1982). Sea urchin production and processing in Liaoning. Fisheries Sciences, 3, 16-20. 